\title{
ECONOMIC FREEDOM OF PERSON IN UKRAINE: THE PAST AND THE MODERNITY
}

\section{Atamaniuk Z. M.}

\section{INTRODUCTION}

The problem of individual freedom was considered by representatives of different scientific schools and fields. The initial concept was the concept of personality. Representatives of the socio-genetic direction (E. Thorndike, B. Skinner, U. Dollard, K. Levin, and others) tried to explain the personality traits based on the structure of society, ways of socialization, and relationships with others. Representatives of the biogenetic approach on the basis of the development of personality and the formation of types of its behavior are biological processes of maturation of the body. S. Hall, for example, believed that the development of personality in a collapsed form repeats the stages of development of society. Another representative of the biogenetic approach E. Kretchmer deduced personality types and their behavior from the peculiarities of the structure of the human body.

Particularly striking is the principle of biological represented in the concept of personality, developed by S. Freud, who believed that all the behavior of the individual due to the physiological, unconscious traits of man.

In the middle of the last century, the concept of cognitive orientation was particularly popular, whose representatives (J. Piaget, D. Kelly, and others) preferred to develop the intellectual-cognitive sphere of the personality psyche. Another direction in the psychogenetic approach was represented by representatives of personal orientation (E. Spranger, A. Maslow, etc.). Their attention was focused on the development of the individual as a whole, on which, in their opinion, their behavior, including deviant, depends ${ }^{1}$. The problem of freedom was considered in numerous works of Western European philosophers of the XIX-XX centuries: J.-P. Sartre, E. Fromm, M. Heidegger, K. Jaspers, Z. Freud, A. Schopenhauer, I. Berlin, O. Velmar, F. Nietzsche and others. Among domestic researchers I. Bychko, K. Novikov, L. Nikolaev, B. Hrushin, V. Parkin, V. Andrushchenko, M. Mikhalchenko, S. Krymsky, and others.

It should be noted that some attention was paid to the problem of personality formation, its behavior in the social philosophy and psychology of the so-called

1 Крысько В.Г. Социальная психология: словарь-справочник. Москва: АСТ, 2001. 688 c. C. 334. 
Soviet period. However, there was no consensus among these scholars, but some experience was gained in interpreting the consideration of the personality, motives, and factors of the formation of deviations in behavior, etc. The problem of personality was considered by S.L. Rubinstein, L.S. Vygotsky, B.G. Ananiev, K.A. Albukhanov-Slavska, A.N. Leont'ev, A.V. Petrovsky, V.V. Myasishchev, K.K. Platonov, D.N. Uznadze, and many others. V.G. Ananyev, for example, considered the personality in the unity of four parties.

In the context of economic freedom, modern scholars turn to the fundamental problems of the theoretical and methodological level, the metaphysics of economics, the philosophy of money, financial civilization, the problems of social responsibility and the economy of knowledge (V.D. Basilevich, T.P. Glushko, V.V. Ilyin, A.A. Mazaraki, S.V. Proleev, Z.E. Skrynnik and others). Ukrainian scientists L. Hubersky, V. Andrushchenko, and M. Mikhalchenko draw attention to the activity as the main source of culture. They note that the connection of culture with human labor, active, transformative educational activities of people ${ }^{2}$.

\section{Historical retrospective of economic thought in Ukraine}

Formation of the Ukrainian people as a separate ethnic community was based on the East Slavic population, which was previously part of a single Ancient Russian state (IX - XII centuries). The peculiarity of the ethnic history of the Ukrainians was that it was formed in the areas that once formed the core of the territory of the Ancient Russian state. The relatively protracted nature of the process of formation of the Ukrainian people and the Ukrainian state was complicated and slowed down by the constant attempts of Lithuania, Poland, Turkey, Hungary, and other neighboring feudal states to include Ukrainian lands and the Ukrainian population in their composition. Despite the political fragmentation of the ethnic territory of Ukrainians, the development of productive forces and the strengthening of economic ties, as well as the political unification of disparate lands in the fight against foreign invaders contributed to the consolidation of the Ukrainian people.

Economic thought in Ukraine during this period is most widely reflected in the literary monument - "n Truth" (XI century). This first code of laws of the homeland of the Ukrainian state contains rich material, which testifies to the existence of signs of a sufficiently developed market economy. The law protected private property, determined the punishment for encroaching on it. Princes and boars had an exclusive and inheritance right to land that even the Grand Duke could not deprive them of.

\footnotetext{
${ }^{2}$ Петинова О.Б. Экономоческий человек: опыт социально-философской экспликации: Монография. Одесса: Печатный дом, 2016. 336 с. С. 63.
} 
"Russian Truth" gives a fairly accurate idea of the currency system and its function of circulation and savings. Unlike the Western European states of the early Middle Ages, where usury was considered sinful, it was legally regulated in Kievan Rus. The Code of Laws approved the procedure for securing the property interests of the creditor, their protection, the conditions following which the requirement of repayment of the loan has legal force, the procedure for collecting debts, etc. The Russian truth did not limit the amount of interest. Adjustment was made only for the percentage of the loan for a relatively short period (from one month to one year). The loan interest rate in Kievan Rus was very high.

The multifaceted work, The Tale of Past Years (late XI - XII; vol.), which was authored by a monk at the Kyiv-Pechersk Nestor Monastery, states that labor is the source of all wealth. Recognizing the natural division of labor in society into mental and physical, Nestor stresses that both types of work both sage and craftsman - are equally important for the welfare of the state. Society needs all kinds of products that enrich the state. Important, according to Nestor, was the division of labor in the production process, because it contributed to the improvement of skill ${ }^{3}$.

The documents of the late Middle Ages recorded a significant spread in Ukraine of patrimonial land ownership, it was interpreted as being given into hereditary possession with the permission of exchange, gift, sale (estate). Some certificates stipulated the possibility of seizure of the demesne from the owner for the benefit of the state, but with the provision of monetary compensation, which was fixed in advance in a "deed of honor" for the right to own the demesne.

Since then, we have come to some nudes that testify to keeping records of income and property. Economic thought reflects the development of usury. Letters of credit show that credit operations are secured by property, including land. Thus, land becomes a commodity.

As the statistics show, the main unit of taxation in the various Ukrainian lands was the plow, plow, yard, yard in the countryside, the house - in the cities, which testifies to the preservation of the ancient taxation measures that were applied since Kievan Rus.

The unique document that became the highest achievement and result of the Ukrainian public opinion of the Cossack time was the Constitution of Philip Orlyk. The ideas expressed in this document are the result of almost a thousand years of socio-economic and political development of Ukraine, a testament to the high level of consciousness of the nation.

\footnotetext{
${ }^{3}$ Проблема людини в сучасній філософії: монографія. Донецьк: ДонНУЕТ, 2008. 219 с.
} 
P. Orlik's constitution stood for the protection of private property. To prevent the landing of ordinary Cossacks and the concentration of sergeant tenure, which at that time led to the revival of feudal serfdom, Article 10 of the Constitution forbade the elders to seize land or forced to sell it.

Much attention is paid to the Constitution in financial affairs. The constitution separated the state treasury from the hetman's and transferred it to the treasurer general. This would create public finances.

The fact that the Constitution raised trade problems testified to the development of commodity-money relations in the Hetmanate. If the markets and auctions were served only by local markets, which provided economic connection between the city and the countryside, then the fairs connected different parts of Ukraine and were a sign that the internal market was developing.

The Constitution set out some areas for improving the taxation of the population. With the abolition of state-owned monopolies, leases, ransoms, the General Council had to find other means of keeping the Cossack army at the disposal of the hetman and carrying out military police orders.

In the socio-economic policy of the Ukrainian hetmans, starting with P. Sahaidachny, attention was paid to the social protection of the population. Although the first Constitution of Ukraine was not implemented, it remained one of the most famous monuments of political and economic thought.

After the reunification of the Left Bank and Right Bank Ukraine, after the second (1793) and third (1795) divisions of Poland and the liberation of the Northern Black Sea, conditions have emerged that accelerated the process of ethnocultural consolidation of Ukrainians, facilitated the specialization of various branches of agriculture and industry, development of domestic economic ties and at the same time attracted Ukraine to the single national market.

After the abolition of serfdom in Ukraine, the development of capitalist relations in all spheres of economy accelerated significantly.

Already in the period of capitalism, under the influence of penetration into the village of commodity relations and urban life forms, some archaic customs and ceremonies gradually take root, new elements in the material life and spiritual life of the peasantry, which constituted the majority of the population (European costume, new types of life, production and modifications, spread, etc.). This process was accompanied by further social and economic stratification of the peasantry, the destruction of its poorest part, the massive agricultural and non-agricultural waste.

A distinctive feature of the development and teaching of political economy at Ukrainian universities was that it was based on the highest achievements of world economic thought. From the beginning of the XIX century the 
connection with the ideas of A. Smith, based on which political economy in Ukraine developed, is traced prominent Ukrainian economist, M.A. Boludiansky (1769-1847). He was the first Ukrainian economist in 1806-1808 to set out and try to develop the basic provisions of Smith's "Wealth of Nations". M.A. Baludiansky correctly identified "Adam Smith's theory of work and exchange" as a system that sees the source of wealth of the people "in the exchange value of all products" .

Kharkiv, Kyiv, and Novorossiysk (now Odesa) universities have become the mainstays of classical political economy, not only in Ukraine but throughout the Russian Empire. The most famous representatives of the classical school were professors TF Stepanov, I.V. Vernadsky, G.M. Tsehanovetsky, M.M. Volsky and others. The Ukrainian scientists mostly turned to the treatment of problems of cost and distribution, capital, money, etc. A. Smith and J.-B. Sei. At the same time, they did not have the simplified reduction of human nature to the primitive "homo economics" of A. Smith (that is, an economic man who is guided solely by his selfish interests). Caring for the accumulation of national wealth is combined in them with the understanding that the achievement of success is possible only based on spirituality, education and moral healing of society. Hence the criticism of Smith's thesis about productive work, wealth.

There are two distinct stages in the development of classical school ideas in Ukraine. The first of them covered the period until the 60's of the XIX century. and was characterized by the influence of physiocracy and later variants of classical political economy. The most famous representative of the physiocratic school that appeared in Ukraine much later than in the West was Vasily Karazin (1773-1842), who initiated the founding of Kharkiv University and the reform of education in the Russian Empire. Quite original Ukrainian scientists solved the question of the connection of people's well-being, entrepreneurship, and management. He emphasized that "people's luxury only breeds the spirit of industry in the states". V. Karazin distinguished between the material, moral and political well-being of the people saw his direct dependence on the population growth, as well as on the method of government.

In the applied aspect, physiocracy found expression in the works of prominent graduates of the Kyiv-Mohyla Academy, agronomists-economists Andrew Samborsky (1732-1815), Mikhail Livanov (1751-1800), Anton Prokopovych-Antonsky (1762-1848) and others. Thanks to the activity of graduates of Kyiv-Mohyla Academy in Ukraine, agronomic centers have been established - Baturyn, Kharkiv, Nizhyn, Mykolaiv and others.

\footnotetext{
${ }^{4}$ Проблема людини в сучасній філософії: монографія. Донецьк: ДонНУЕТ, 2008. 219 с.
} 
Prominent page in the development of the ideas of the classical school in Ukraine was the work of the first teacher of political economy at Kharkiv University (he worked here in 1805-1806 and 1810-1819) Professor Joseph Lang.

In the paper On the Higher Principle of Political Economy (1807), J. Lang developed the ideas of F. Kahn's "Economic Table" and also created a threesector model of the national economy. But, unlike the Kenyan Economic Table, it distinguishes agricultural, industrial and monetary sectors in the economy.

In the field of political economy, Ukrainian scholars D. Zhuravsky, G. Stepanov, I. Vernadsky, and other representatives of the classical school used the theory of labor value to substantiate the historical necessity of the capitalist path of socio-economic development. The crisis of the feudal-feudal system, the gradual penetration of capitalist relations in all branches and spheres of economy - and the axis around which controversy arose over the application of key concepts of classical political economy.

At the next stage of the development of the ideas of the classics, which covered the second half of the nineteenth century, the problem of the capitalist development of the economy of Ukraine within the Russian Empire became central. Accordingly, not only research problems have changed, but more favorable conditions for the development of economic science have emerged. Works of representatives of Ukrainian classical political economy of the second half of the 19th century A. Antonovich, G. Tsehanovsky, M. Kossovsky, and others marked by a critical analysis of previous theories of value and income sharing, the search for new concepts.

However, some representatives of economic science (M. Sieber, M. Kossovsky) analyzed in detail the theory of value (value) and other theories of classical and Marxist political economy, and quite favorably treated K. Marx's economic theory and popularized it.

The ideas of Marxism were developed in Ukraine by M. Sieber, a graduate of Kyiv University. K. Marks recognized in the personality of M. Sieber a scholar of European scale, which, of course, is a compliment to all Ukrainian economic science. Emphasizing the method of the researcher, he thus confirmed that M. Ziber's purpose was not at all reduced to commenting and promoting the Capital. The purpose of the scientist was to concretize and deepen the theory of labor, the basis of which was laid by representatives of the Smith - Riccardo Science School ${ }^{5}$.

In his fundamental study, Essays on Original Economic Culture, Sieber refuted the concept of the Russian model of communal socialism, which was

\footnotetext{
${ }^{5}$ Проблема людини в сучасній філософії: монографія. Донецьк: ДонНУЕТ, 2008. 219 с.
} 
opposed by European and Ukrainian scholars. In this connection, it makes sense to recall the prominent Ukrainian scientist I. Vernadsky, who began his scientific research during the period of fascination with the populist messianic that arose, based on the fact of the community's existence in Russia and its absence in Ukraine.

Pointing to the general capitalist tendencies in the economic development of Russia, M. Sieber described his national forms and features of capital accumulation. For example, he attributed the theft to such sources of capital growth, which could be called exclusively Russian "specialty". The researcher illustrates his evidence with many facts that testify to Russia's economic backwardness, which is due, among other things, to the preservation of socioeconomic and legal support of despotism. It is necessary to counteract the negative effects of capitalism, but to eliminate it until it has exhausted itself, one cannot think, because it is like lifting one's hair by him.

This was M. Ziber's conclusion about the cause of the development of capitalism from Russia, which has been hindered by a community that has long ceased to exist in the home country of the scientist, the defender of the economic and political freedom of the peoples. No wonder the researcher mentioned the entrepreneurship and love of the Cossacks, who defended the will with incredible energy and which the government of Moscow approved for this.

A prominent economist has considered the processes of economic development in many countries. These are communities and states in the Netherlands, communal land relations in medieval Alsace, the history of the Swiss almenda, the fate of public ownership in Switzerland, the agrarian question in Ireland, the state of agriculture in England and more. Rich in rich factual material, based on the best achievements of economic theory and history of the time, these studies by M. Sieber still have not lost their cognitive significance.

M. Sieber's ideas influenced such prominent thinkers as I. Franko, S. Podolynsky, M. Drahomanov, A. Terlensky, and others. The scientific creativity of the researcher M. Tugan-Baranovsky was positively evaluated. Particularly productive was M. Sieber's influence on Russian economic thought in his search for theoretical support for overcoming populist ideology.

The rapid changes that have taken place with our society in recent years have brought to life many things, both positive and negative. The diversity of modern forms of social life is to be studied in philosophy: "The social sciences are like biology, but unlike most branches of physical knowledge, they study structures whose characteristics can only be represented by models constructed on a relatively large number of variables"

6 Словари и энциклопедии. Режим доступу: https://dic.academic.ru/dic.nsf/ruwiki/ $1140828 /$ 
According to one of the most famous futurists of today, Alvin Toffler, with societies that fall into the circle of rapid change, there are often various "troubles" because people do not have time to adapt to the new and adequately perceive it. In such societies, the destruction of old values often leads to the destruction of any culture at all, except for its most primitive manifestations. The psychology of mass violence is being formed. Relationships are reduced to the problem of survival, to combat themselves by any means.

Such a situation leads to the self-destruction of society in the physical sense, or the destruction of it as a historical unit and displacement into the yards of history.

For Ukrainian society today, this becomes a very real prospect, if it does not have time to form a strong enough core capable of resolute opposition to the process of self-destruction, to constructive action.

A. Toffler claims that five percent of the non-marginalized population is enough to keep the situation from becoming hopeless. So, are they in us? Will modern Ukrainian society survive without leaving behind Ruin? Will a civilized way of building a truly independent Ukrainian state be found?

But knowledge is acquired through education. And access to it is not always exist. Therefore, there are more and more reasons to speak about the two main classes of society in developed countries: the educated and the uneducated $^{7}$. And if the former, in fact, largely already live in the posteconomic era, when the creative, rather than the necessary content of labor comes to the fore, then the latter are firmly entrenched in the realm of labor as a necessity. This phenomenon points to one form of alienation of intelligence due to its concentration in a particular social group.

\section{Economic freedom of the individual}

In the 21 st century, modern man is surrounded on all sides by necessities (for example, proper behavior). It obeys both the physiological and social laws of the society in which it resides directly, its rules and norms. On all sides, it is surrounded by certain generally accepted norms of behavior, traditional actions, and rituals. And also an important aspect is consideration and economic need.

For example, for most representatives of ancient philosophy - Socrates, Diogenes, Epicurus, and Seneca - freedom is the meaning and purpose of human existence. For the representatives of medieval scholasticism - Anselm of Canterbury, Albert the Great and Thomas Aquinas - freedom of reason and

7 Муляр В.І. Самореалізація особистості як соціальна проблема / філософсько культурологічний аналіз. Житомир: ЖІТІ, 1997. 214 с. 
actions is possible only within the limits of church tenets, outside which their freedom is a heresy, a grave sin. In modern times, it becomes the dominant view of freedom as a natural state of man, the path to social equality and justice (Thomas Hobbs, Paul Henry Holbach, Pierre Simon Laplace). Representatives of German classical philosophy also paid great attention to the problem of freedom. Immanuel Kant, for example, understood freely the intelligent (that is, inaccessible to sensory cognition) nature of man; for Johann Gotlieb Fichte freedom is the only absolute reality; and George Wilhelm Friedrich Hegel understood under liberty the multifaceted reality, which in all its manifestations is a form of objectification of the absolute spirit ${ }^{8}$.

Significant contribution to the development of this category was made by Benedict Spinoza, Jean-Jacques Rousseau, Voltaire, Karl Marx, Friedrich Engels, Arthur Schopenhauer, Friedrich Nietzsche, Jean-Paul Sartre, Karl Jaspers, Nikolai Berdyaev, Vladimir Solovyolov, Vladimir Solovyonov, Vladimir Solovyonov, Vladimir other philosophers and thinkers. As we can see, there are many approaches to the concept of "freedom", and this proves once again that freedom is an extremely complex, multidimensional phenomenon? .

Modern economic science is in a protracted methodological crisis, first of all, because, according to O.I. Davydov and G.V. Zadorozhny, it does not try to get out of the format of the mechanical-materialistic paradigm, the research within which the sphere of spiritual production does not touch, that is, continues to work "model of economic man, as a certain account line of his selfish economic interests (S.M. Bulgakov). "A person in economics is more (for one school) or less (for other schools) a rational egoist who maximizes his utility (which is usually equated with money) and minimizes his expenses (above all, labor). If in this paradigm there is a problem of human qualities, then only to turn a person into a special kind of capital and continue to be viewed only from one angle: in the development of which of them the most profitable to invest" $" 10$.

Modern economic science, especially economics, is not aimed at exploring the whole economic world as a reality. For historical reasons and reasons, it has separated the realm of the economy from reality, without even explaining that the economy is only a separate, specific form of economy, and "builds"

\footnotetext{
${ }^{8}$ Воецкая Т.В. Курс философии. Одесса: ОКФА, 1999. 616 с.

${ }^{9}$ Бачинин В.А. Морально-правовая философия. - Харьков: Консум, 2000. 208 с.

10 Бузгалин А.В., Колганов А.И. Современная политзкономия: альтернативи “зкономическому империализму”. Политэкономия: социальные приоритеты. $T$. 1: От кризиса $к$ сочиально ориентированному развитию: реактуализация политической экономии. М.: ЛЕНАНД, 2013. С. 43.
} 
economic knowledge in the face of many constraints and the introduction in each case of a number of conditions, which greatly contributes to the removal of economic knowledge from those realities in which man really lives and maintains his economy. On the other hand, the economic system itself is regarded by the economy as self-sufficient, moreover - as a dominant in society, trying to impose in all spheres of society economic interest and commodity-money relations, as well as to subordinate economic power to all that exists in human society.

That is why economics today, as well as science in general, is tasked with "creating a new picture of reality that is adequate to reality itself, and not one that proceeds from the mass of previous reservations and constraints through which reality itself is lost or unrecognized. And further, science is already studying not reality, but its vision, interpretation of reality that is, some virtual-abstract, science-created, model, and tries to practically propose some measures based on the model, not reality. Therefore, the situation in the most economic reality is becoming more crisis, destructive, which threatens man and humanity ${ }^{11}$.

Such a real shattering situation, which has developed over the last twenty years in the post-Soviet countries, was because neoclassical economic science (economics as a mainstream), first, imposed an extremely simplified, misplaced understanding of economic freedom. In a state of general euphoria about the rapid effects of market reforms, economists and politicians did not think that "capturing a misunderstood concept of economic freedom can produce the opposite of expected effects and thus seriously counteract the recovery in the country" ${ }^{\prime 2}$. On the flip side of freedom - the responsibility of the language has not been spoken and is now almost gone. However, according to the results of modern human studies, perhaps the most fundamental value in the sphere of human relations, in the sphere of creative self-realization of the individual is freedom-responsibility ${ }^{13}$, which in the spiritual world of man correlates with what is defined in the physical dimension as space-time. Awareness of the acute contemporary problems of human survival, as justified more than half a century ago by Karol Wojtyla

11 Задорожний Г.В., Колупаєва І.В. Людська діяльність: зміст і трансформація структури у сучасному господарському розвитку. Харків: Харківський національний університет імені В.Н. Каразіна, 2009. С. 23.

12 Гринберг Р.С. Современная политическая экономия: экономическая свобода и социальная справедливость. Политэкономия: социальные приоритеты. Москва: ЛЕНАНД, 2013. C. 19.

13 Задорожний Г.В., Колинько О.Г. Хозяйствование как процессе ответственной объективации глубинного ценностно-знаниевого первоначала человека. Социальная экономика. 2013. № 1. С. 18-20. 
(Pope John Paul II), has led to the need to replace the Kantian categorical imperative "act in a way that you never treat your face as a means, but always as a goal" with the new imperative of realistic responsibility, which is connected with the responsibility of the person in the face of eternity ${ }^{14}$.

Second, the implanted methodology of individualism in a practical sense turned to ignore the interests of society and comprehensive domination of selfish sentiments, which began to aggressively push human socially significant values of development into the background. "It has become evident that the elevation of selfishness to the rank of public virtue causes serious damage to the ethical hold of society. Frenzy in the pursuit of hedonism, consumerism, and comfort supersede values such as pity, compassion, and solidarity, generating disconnect and apathy in society. At the same time, protest sentiments crystallized, however, without noticeable success in formulating clear alternative models of a more humane social system" Third, a quasi-religious belief in the power of market self-regulation that is capable of ensuring prosperity and prosperity, even among economists, has become dominant even among economists. Such an installation stemmed from the uncritical fallacy of the thesis that, as P. Ulrich wrote, "economist speaking briefly and above all without any" exact "definitions - is a belief in economic rationality only in itself and in nothing else" 16 .

Fourth, spiritual and moral values and moral and ethical norms came to be regarded as harmful in an economic society, impeding the continued growth of profit and capital. "The spiritlessness of economic society stems from its essence as an expression of a transformative and consumerist attitude to the world. Not balanced by altruistic and service, caring for the destiny of the destructive consumption of nature, the inevitable transfer of this attitude to humans makes the economy from a means of development to a means of undermining it. An economic person becomes impersonal... "It is limited to commodity production. But it is for production. However, these qualities are usually transferred to the culture, and in the loss of soul and spirit, the actual living principle can even be proud"17.

14 Твердислова Е. Слово как логика явления. Феноменологический опыт Кароля Войтылы. Войтыла Кароль (Папа Римский Иоанн Павел II). Личность и поступок. М.: Издательство Московского университета, 2010. С. 12-13.

15 Твердислова Е. Слово как логика явления. Феноменологический опыт Кароля Войтылы. Войтыла Кароль (Папа Римский Иоанн Павел II). Личность и поступок. М.: Издательство Московского университета, 2010. С. 12-13.

Твердислова Е. Слово как логика явления. Феноменологический опыт Кароля Войтылы. Войтыла Кароль (Папа Римский Иоанн Павел II). Личность и поступок. М.: Издательство Московского университета, 2010. С. 12-13.

${ }^{16}$ Ульрих П. Критика экономизма. Москва: Вузовская книга, 2004. С. 18.

${ }^{17}$ Ульрих П. Критика экономизма. Москва: Вузовская книга, 2004. С. 18. С. 191-192. 
Of course, such anti-human values of neoliberalism could not fail to lead to the polysystemic crisis of human society, and this crisis itself became quite evident evidence of the failure of neoclassical economic science regarding its ability to comprehensively understand the world of economy as a sphere of holistic human life and to argue through.

The dominance of such an approach in the field of modern economic research creates a situation where scientific search extends only to the "applied, instrumental level, plunging into partial and secondary, derivative activities", and "the object of analysis... quite often empty voices appear, contrived situations that have no real practical significance, and the analysis itself is conducted as another logical exercise for which the author does not know"

It is natural enough that no further evidence is needed to conclude that "mainstream, economics, microeconomics, macroeconomics, international economics and other components of economic theory of this methodological orientation are unable to answer historical challenges. Their categorical composition, tools, various models, forecasts, etc. are adapted to the analysis of a largely balanced economy, to solving problems of functioning of the economy, and the real economy is in a state of significant transformations that change not only the forms but also the content of economic processes. That is why the scientific achievements of some Nobel laureates, as it turned out, were well solved only by local issues of the functioning of the economy, and in the future created the basis for deepening economic imbalances and increasing economic risks.

Freedom - in its absolute sense - is a course of events such that the will of every actor in these events is not subject to violence by the will of others.

Freedom - in the most general sense - is the ability to choose, options for the outcome of an event. Lacks of choice, variants of the event are equivalent to a lack of freedom. Freedom is a kind of contingency directed by free will (directional will, conscious freedom) or stochastic law (unpredictability of the result of an event, unconscious freedom). In this sense, the concept of "freedom" is opposite to the concept of "necessity." In ethics, "freedom" is associated with the presence of free will of man. Freedom of will imposes responsibility on a person and puts at the merit of his words and deeds. An act is considered moral only if it occurs under the condition of free will, is the free will of the subject. In this sense, ethics is aimed at realizing a person's freedom and the responsibility associated with it. In the right notion of freedom is connected not only with the responsibility of the subject for his actions, but also with the degree of responsibility - the degree of conviction or recklessness of the act In law, the possibility of certain human behavior (eg, freedom of speech, freedom of religion, etc.) enshrined in the constitution 
or other legislative act. The category of "freedom" is close to the concept of "right" in the subjective sense, but the latter implies the existence of a more or less clear legal mechanism for the implementation and usually appropriate obligation of the state or other entity to take any action (for example, to provide work in the case of the right to work). On the contrary, legal freedom does not have a clear mechanism of implementation; it is the duty of it to refrain from exercising any violation of this freedom of action ${ }^{18}$.

Freedom - a means to achieve the purpose and meaning of human life. For pagans, the ideals of freedom served as the basis for the creation of a democratic society, the classic example of which was Athens in ancient Greece. In recent centuries, modern ideals have returned to these ideals ${ }^{19}$. The relevance of research into the problems of individual freedom is caused, first, by the development of opportunities to create favorable conditions for selfrealization in society. The purpose of such a process is to formulate a coherent concept of individual freedom of personality, which would be filled with specific content, reflecting the real activity of the individual as an individual and as a member of society. Therefore, in the context of the socialphilosophical theory of freedom of particular meaning, the problems of individual, personality-oriented freedom and the formation of the individual in the structure of the individual considered in the conditions of transformation of the social system take on a special meaning. This has aroused our interest in the problems of economic freedom ${ }^{20}$.

Economic freedom in practice means the right to start or terminate your own business, buy any resources, use any technology, produce any product and offer it for sale at any price, to invest your own money. It should be understood that these rights do not guarantee a guaranteed success for every entrepreneur. He can produce any product, set at any price. However, there is no guarantee that someone will buy it, since consumers also enjoy economic freedom, that is, freedom of personal choice, which is no less important than freedom of enterprise. Every consumer has the right freely to buy any product or service, to offer his services for the performance of any work; to refuse any work; use your resources, provided that it does not infringe upon the rights of others. These rights of liberty also give no guarantee, i.e. the entrepreneur has the right to offer his services, but no one can be forced to accept them.

The economic freedoms of entrepreneurs are closely interconnected. When a business is privately owned, then encroaching on the freedom of enterprise

\footnotetext{
${ }^{18}$ Ильинский И.М. Свобода - путь к знанию, пониманию, умению. Знание, понимание, умение. 2004. № 1. Режим доступа: http://www.zpu-journal.ru/zpu/2004_1/llinskiy/3.pdf

${ }^{19}$ Словари и энциклопедии. Режим доступу: https:/dic.academic.ru/dic.nsf/ruwiki/1140828/

${ }^{20}$ Словари и энциклопедии. Режим доступу: https:/dic.academic.ru/dic.nsf/ruwiki/1140828/
} 
is encroaching on the freedom of the owner of the property. Without economic freedom, there can be no freedom of the individual $^{21}$. An entrepreneur can only be an economically separated, self-managing entity.

Economic freedom is impossible without a market, nor can a market exist without economic freedom. It is the market through various mechanisms of functioning that provides real conditions for the economic freedom of the entrepreneur. In other words, the market mechanism of management objectively provides for freedom of management. Economic freedom has its basic principles, namely: economic independence, economic responsibility, and economic equality ${ }^{22}$.

Economic independence consists in the presence of the property rights of the entrepreneurs, the right to independently choose the form of ownership and economic form, independent planning of their financial and economic activity, free disposal of profit, independent choice of resources, suppliers and consumers of manufactured products, establishment of various forms, systems and sizes wages and more.

Economic responsibility is the responsibility of the entrepreneur with his property for the results of management. Failure to meet contractual obligations in terms of time and quality should be covered by penalties, which will include not only direct losses but also the lost advantage. The entrepreneur bears property and other statutory liability for the damage and damages caused.

Economic equality. It is about equal (equal) economic conditions for any economic activity, regardless of ownership and economic activity. Equal economic conditions mean uniform pricing, taxation, profit sharing, investment and credit policy, government contracts, etc. The state must guarantee all entrepreneurs, regardless of their chosen organizational forms of business activity, equal rights and create equal opportunities for access to material, technical, financial, labor, natural, information and other resources. It should be noted that some areas of activity or organizational form have (or may have) certain benefits. For example, small enterprises, or enterprises, have certain tax exemptions; they carry out agricultural production activities, and so on. It is through these basic principles - economic autonomy, economic responsibility and economic equality - that the freedom of economic activity, which is the basic prerequisite for the development of business activity, is realized to a certain extent ${ }^{23}$.

\footnotetext{
${ }^{21}$ Воецкая Т.В. Курс философии. Одесса: ОКФА, 1999. 616 с.

${ }^{22}$ Воецкая Т.В. Курс философии. Одесса: ОКФА, 1999. 616 с. С. 188.

23 Гетьман О. Економіка підприємства: Навчальний посібник / Оксана Гетьман, Валентина Шаповал. Киъв: Центр навчальної літератури, 2006. 487 с.
} 
Model of economic man of Ukraine, researched by Petinova $\mathrm{OB}^{24}$ in the approach to historical, economic, national, cultural specificity finds specific features. In the studies of Ukrainian scientists, this feature is explained, for example, by the fact that the patterns of behavior displayed in the model do not have time to change as quickly as the external conditions and the social environment. In conditions of instability in society, "transitional" forms of human activity are born; values and norms of behavior are tested in fundamentally new, unfamiliar and unusual circumstances. The model of "Ukrainian economic person" should be constructed as close to reality as possible, taking into account the motivation and influence of uncertainty on the economic state of society. In addition to the main features of Western models, the Ukrainian version emphasizes the role of social, legal, political, national, moral, environmental factors ${ }^{25}$, as well as the "economic orientation of the individual, according to the conditions in which it was formed". Special attention is paid to the analysis of human, intellectual capital ${ }^{26}$.

Man in economic relations, modifications of economic behavior has been and is an actual subject of study in the socio-philosophical, sociological, philosophical and economic tradition. Particularly important and significant on the scale of socio-philosophical relevance is this aspect of human study for Ukraine, which is going through a difficult stage of economic formation of an independent state.

An analysis of the epistemological potential of a general scientific method of modeling showed the presence of a set of properties necessary for the implementation of multidisciplinary theoretical research programs. Modeling of economic phenomena and processes is the main method of research in economic theory. It embodies the reflexive-symmetric relationship between theoretical and empirical forms of knowledge. The model as a way of representing and interpreting the object, its simplified version, reveals the specifics of the phenomenon under study. Simulation makes it possible to predict the behavior of real systems and optimize their functioning. The economic man model within theoretical and empirical contexts reflects changing combinations of complex economic, ideological, socio-cultural, psychological, spiritual, political, ethical discursive interactions.

Economic thinking as a process of ideally reflecting the subject of knowledge of economic processes and phenomena (through which a person

\footnotetext{
${ }^{24}$ Петинова О.Б. Экономоческий человек: опыт социально-философской экспликации: Монография / Петинова О.Б. Одесса: Печатный дом, 2016. 336 с.

${ }^{25}$ Петинова О.Б. Экономоческий человек: опыт социально-философской экспликации: Монография / Петинова О.Б. Одесса: Печатный дом, 2016. 336 с. С. 261-262.

${ }^{26}$ Петинова О.Б. Экономоческий человек: опыт социально-философской экспликации: Монография / Петинова О.Б. Одесса: Печатный дом, 2016. 336 с. С. 261-262.
} 
finds an adequate idea of economic reality, develops a mechanism for coordinating economic behavior), closely interacts with economic (economic) culture. It refers to a particular socialized sphere of human activity, "processed" by its place of existence. It is usually associated "with the formation, organization, and reproduction of relationships between members of society", which arise and consist in joint activities aimed at providing and meeting "primary needs for food and shelter, as well as needs for other goods and services" 27 . The economy interacts with the broad context of the cultural substrate of society, resulting in a certain type of economic culture in all its various forms. General organizational forms of economic culture (in accordance with encyclopedic information) include the type of economic organization; predominance of collective or individual activity; large or small business units; rigid or free labor regulation; types of economic entities; the degree of intensity of economic space development by different economic entities; types of technologies they use; degree of realization of economic actions and goals at the level of different economic entities; their economic efficiency.

Criteria for public assessment of economic culture can be the level and structure of needs of economic agents, stereotypes of consumption, the ratio of aggregate demand and aggregate consumption; value-motivational relations of different socio-cultural groups to work, wealth, accumulation (ethics of economic life); assessment of the place of economy in a given society and its social effectiveness.

\section{CONCLUSIONS}

Despite the political fragmentation of the ethnic territory of Ukrainians, the development of productive forces and the strengthening of economic ties, as well as the political unification of disparate lands in the fight against foreign invaders contributed to the consolidation of the Ukrainian people.

The processes of reform, which are taking place in all spheres of our society, relate to economic, political, social, domestic and other relations in the need of scientific and theoretical studies of the problems of formation and development of social and philosophical aspects of personal freedom.

The relevance of research into the problems of individual freedom is caused, first of all, by the development of opportunities to create favorable conditions for self-realization in society. The purpose of such a process is to formulate a coherent concept of individual freedom of personality, which

\footnotetext{
${ }^{27}$ Петинова О.Б. Экономоческий человек: опыт социально-философской экспликации: Монография / Петинова О.Б. Одесса: Печатный дом, 2016. 336 с. С. 282.
} 
would be filled with specific content, reflecting the real activity of the individual as an individual and as a member of society.

Freedom - a means to achieve the purpose and meaning of human life. Freedom is a fundamental characteristic of human existence, because freedom is not what people possess, but what they are in their essence. As a universal characteristic of human beings, freedom refers to a person's ability to choose and manage his or her existence and is directly related to a sense of dependence, alienation, and responsibility.

Economic freedom in practice means the right to start or terminate your own business, buy any resources, use any technology, produce any product and offer it for sale at any cost, invest your own money. Every consumer has the right freely to buy any product or service, to offer his services for the performance of any work; to refuse any work; use your resources, provided that it does not infringe upon the rights of others. These rights of liberty also give no guarantee, ie the entrepreneur has the right to offer his services, but no one can be forced to accept them.

Conomic freedom has its basic principles, namely: economic independence, economic responsibility, and economic equality.

\section{SUMMARY}

The article deals with the economic thought of Ukraine in retrospect, as well as modern views through the lens of the problem of individual freedom. The peculiarity of the ethnic history of the Ukrainians was that it was formed in the areas that once formed the core of the territory of the Ancient Russian state. The relatively lengthy nature of the process of formation of the Ukrainian people and the Ukrainian state was complicated and slowed down by the constant attempts of Lithuania, Poland, Turkey, Hungary, Russia, and other neighboring states to include Ukrainian lands and the Ukrainian population. Despite the political fragmentation of the ethnic territory of Ukrainians, the development of productive forces and the strengthening of economic ties, as well as the political unification of disparate lands in the fight against foreign invaders contributed to the consolidation of the Ukrainian people.

In the context of economic freedom, modern scholars turn to the fundamental problems of the theoretical and methodological level, the metaphysics of economics, and the philosophy of money. Today, economic science, as well as science in general, is tasked with "creating a new picture of reality that is adequate to reality itself, not one that proceeds from the mass of previous reservations and constraints through which reality itself is lost or unrecognized. And further, science is already studying not reality, but its vision, interpretation of reality, which is, some virtual-abstract, science- 
created, model, and tries to practically propose some measures based on the model, not reality.

Freedom - a means to achieve the purpose and meaning of human life.

Economic freedom in practice means the right to start or terminate your own business, buy any resources, use any technology, produce any product and offer it for sale at any cost, invest your own money.

Economic freedom has its basic principles, namely: economic independence, economic responsibility, economic equality.

\section{REFERENCES}

1. Бачинин В.А. Морально-правовая философия. Харьков: Консум, 2000. $208 \mathrm{c}$.

2. Бузгалин А.В., Колганов А.И. Современная политзкономия: альтернативи “зкономическому империализму”. Политэкономия: социальные приоритеты. Т. 1: От кризиса к сочиально ориентированному развитию: реактуализация политической экономии. М.: ЛЕНАНД, 2013. C. 43.

3. Воецкая Т.В. Курс философии. Одесса: ОКФА, 1999. 616 с.

4. Гетьман О. Економіка підприємства: Навчальний посібник / Оксана Гетьман, Валентина Шаповал. Киъв: Центр навчальної літератури, 2006. 487 с.

5. Гринберг Р.С. Современная политическая экономия: экономическая свобода и социальная справедливость. Политэкономия: социальные приоритеты. Москва: ЛЕНАНД, 2013. С. 19.

6. Задорожний Г.В., Колинько О.Г. Хозяйствование как процессе ответственной объективации глубинного ценностно-знаниевого первоначала человека. Социальная экономика. 2013. № 1. С. 18-20.

7. Задорожний Г.В., Колупаєва І.В. Людська діяльність: зміст і трансформація структури у сучасному господарському розвитку. Харків: Харківський національний університет імені В.Н. Каразіна, 2009. С. 23.

8. Ильинский И.М. Свобода - путь к знанию, пониманию, умению. Знание, понимание, умение. 2004. № 1. URL: http://www.zpu-journal.ru/ zpu/2004_1/Ilinskiy/3.pdf

9. Крысько В.Г. Социальная психология: словарь-справочник. Москва: АСТ, 2001. 688 с.

10. Муляр В.I. Самореалізація особистості як соціальна проблема / філософсько - культурологічний аналіз. Житомир: ЖІTI, 1997. $214 \mathrm{c}$.

11. Петинова О.Б. Экономоческий человек: опыт социально-философской экспликации: Монография. Одесса: Печатный дом, 2016. 336 с. 
12. Петинова О.Б. Экономоческий человек: опыт социальнофилософской экспликации: Монография / Петинова О.Б. Одесса: Печатный дом, 2016. 336 с.

13. Проблема людини в сучасній філософії: монографія. Донецьк: ДонНУЕТ, 2008. 219 с.

14. Словари и энциклопедии. Режим доступу: https://dic.academic.ru/ dic.nsf/ruwiki/1140828/

15. Твердислова Е. Слово как логика явления. Феноменологический опыт Кароля Войтылы. Войтыла Кароль (Папа Римский Иоанн Павел II). Личность и поступок. М.: Издательство Московского университета, 2010. C. 12-13.

16. Ульрих П. Критика экономизма. Москва: Вузовская книга, 2004. C. 18. C. 191-192.

\section{Information about the author:}

Atamaniuk Z. M.,

Candidate of Philosophy, Associate at the Department of Philosophy, Sociology and Management of Socio-Cultural Activity, State Institution "South Ukrainian National Pedagogical University named after K. D. Ushynsky" 26, Staroportofrankivska str., Odesa, 65020, Ukraine 